\title{
Zygmunt Bauman
}

\section{Antonio Gramsci, \\ czyli socjologia w działaniu}

Nota od Redakcji

Prezentowany w skróconej wersji w dziale Archiwum tekst Zygmunta Baumana pierwotnie ukazał się w czasopiśmie „Kultura i Społeczeństwo” w 1963 roku (w numerze 1, s. 19-34).

Następnie w formie niezmienionej opublikowany został jako szósty rozdział książki Wizje ludzkiego świata. Studia nad społeczna geneza i funkcją socjologii, Książka i Wiedza, Warszawa, 1964, s. 335-363.

Socjologia w działaniu Antonio Gramsciego (obok socjologii zaangażowanej Charlesa Wrighta Millsa) została potraktowana jako przykład „inżynierii przez racjonalizację" (czyli socjologii krytycznej) przeciwstawionej ,inżynierii przez manipulację" (czyli nauce o zachowaniu). Tę drugą Bauman opisał, posługując się przykładami socjologicznej teorii Talcotta Parsonsa (Talcott Parsons, czyli konserwatyzm skodyfikowany) i George'a Lundberga (George Lundberg, czyli dehumanizacja humanistyki).

Metafora inżynieryjna oddać miała w latach 60 . XX wieku wizję ludzkiego świata i działań praktycznych opartych na wykorzystaniu wiedzy teoretycznej, ale z nią nietożsamych.

„Samo sformułowanie teorii, konstruowanie organizującej wizji ludzkiego świata — pisał Bauman ponad pół wieku temu - [...] jest już inżynierią, bowiem zmienia społeczny układ sił i stosunków i w jakiś sposób oddziaływa na bieg historycznego procesu. Wiedza społeczna $\mathrm{z}$ tego tytułu, że zawsze zawiera jakąś wizję ludzkiego świata, jest też zawsze inżynierią przez racjonalizację w potencji; staje się nią faktycznie wtedy i tylko wtedy, gdy organizuje działanie jakichś realnych sił społecznych. Ale też wtedy działalność teoretyczna zespala się z inżynieryjną, staje się samą inżynierią i pozór odmienności refleksji i działania społecznego, mający swe źródła teoriopoznawcze w instytucjonalnym rozgraniczeniu myślicieli i praktyków społecznych, teoretyków i polityków — zostaje 
przezwyciężony. Znakomitą analizę tego typu inżynierii społecznej dał Antonio Gramsci” (s. 38-39).

„Lud »odczuwa«, ale nie zawsze rozumie lub wie, element inteligencki »wie«, ale nie zawsze rozumie, a zwłaszcza nie zawsze »odczuwa«. [...] Błąd intelektualisty polega na tym, i sądzi on, że można »wiedzieć«, nie rozumiejąc, a zwłaszcza nie odczuwając iż nie żywiąc namiętności (nie tylko dla samej wiedzy, ale również dla przedmiotu wiedzy), czyli że można być intelektualistą, a nie zwykłym pedantem, żyjąc w oderwaniu od ludu, nie odczuwając żywiołowych namiętności ludu, nie rozumiejąc ich, nie szukając wyjaśnienia i uzasadnienia w określonej sytuacji historycznej, nie wiążąc ich dialektycznie z prawami dziejowymi, z wyższym, naukowo wypracowanym światopoglądem, z »wiedzą«. Nie można tworzyć polityki - historii bez tej namiętności, czyli bez ścisłej więzi uczuciowej między intelektualistami a ludem"1.

Tymi słowami dał Gramsci wyraz swojej koncepcji socjologii, pojmowanej szeroko jako wiedza społeczna, więcej nawet, jako „filozofia praktyki”; socjologia miała urzeczywistnić styk między „namiętnościami ludu” a „wiedzą intelektualistów", miała tłumaczyć namiętności na język wiedzy, wiedzę na język namiętności i dzięki temu stawać się ważną świadomościową komponentą „bloku historycznego”, elementem kreatywnego działania historycznego. Miała stać się zespoleniem nieuświadomionych cierpień ze świadomością procesu historycznego, służącym przekształcaniu historii w proces świadomy, wiodący do likwidacji cierpień. Jest to więc nie tylko program socjologii zaangażowanej, jak u Millsa, jest to program socjologii działającej, program socjologii, która — posiłkując się słowami Marksa — staje się siłą materialną, gdy opanowuje masy. [...]

W tej wizji świata człowiek i historia stanowią jedność; każdy z członów tej jedności może być zrozumiany tylko przez odniesienie do drugiego. W tej wizji zarazem jest organicznie zawarta inna jeszcze wizja: poznania społecznego splecionego w jeden proces ze społecznym działaniem. Jest to całkiem szczególna i niemająca odpowiednika cecha marksistowskiej koncepcji socjologii, często pomijana lub lekceważona na rzecz referowania kilku czy kilkunastu „twierdzeń empirycznych”, jak gdyby socjologia marksowska dawała się przedstawić w manierze pozytywistycznej nauki. A w tej przecież cesze ukryty jest klucz do zrozumienia marksowskiej wizji społecznego świata, którą Gramsci — jakże słusznie - nazwał „filozofią praktyki”. Ta więc cecha socjologii marksistowskiej, nie zawsze uwypuklana dostatecznie jasno, niekiedy

${ }^{1}$ A. Gramsci, Niektóre zagadnienia z zakresu badań nad filozofia praktyki, [w:] Pisma wybrane, t. I, Warszawa 1961, s. 94-95; przekład Barbary Sieroszewskiej. 
zapominana, niekiedy o prostu nierozumiana, będzie głównym przedmiotem niniejszego szkicu.

\section{Człowiek w historii}

Socjologia marksistowska, jak i wszelka inna, jest próbą uchwycenia stałych elementów w zmiennej i z pozoru niepowtarzalnej w swej zmienności sytuacji człowieka. Jej motywem do zajmowania się wiedzą społeczną i punktem wyjścia jest więc człowiek. Jeśli koncentruje ona w końcu uwagę na społeczeństwie jako całości i procesie historycznym, to dzieje się tak dlatego, że w tych właśnie wielkich i masowych zjawiskach wykrywa korzenie człowieka i sprężyn jego losów. „Człowieka trzeba pojmować jako serię aktywnych stosunków (proces). [...] Jednostka nie wchodzi w stosunki z innymi ludźmi jako ich przeciwstawienie, ale organicznie, to znaczy w tej mierze, w jakiej wchodzi w skład pewnych organizmów, od najprostszych do najbardziej złożonych. [...] Stosunki te nie są mechaniczne. Są aktywne i świadome, czyli zależą od większego czy mniejszego stopnia zrozumienia ich przez poszczególnego człowieka. Toteż powiedzieć można, że człowiek zmienia sam siebie i przekształca w tym stopniu, w jakim zmienia i przekształca całokształt stosunków, którego stanowi centralny węzeł. W tym sensie rzeczywiście filozofem może być jedynie polityk, czyli człowiek aktywny, dokonujący przemian w środowisku, przy czym przez środowisko rozumiemy całokształt stosunków, w których uczestniczy każda jednostka. [...]”2. W tej dynamicznej i dialektycznej wizji człowieka i historii dylemat ,jednostka czy społeczeństwo”, „myśl czy działanie”, stanowiący przedmiot zaciekłych sporów rozmaitych szkół socjologicznych, jest „zdjęty”, przestaje być dylematem. Dwie gnozeologicznie wytłumaczalne abstrakcje, przeciwstawione sobie nawzajem w myśli, odnalazły swą jedność organiczną w historii człowieka czy też człowieku historycznym, będącym zarazem twórcą i tworem swego świata. [...] Dla Gramsciego teoria i praktyka stanowią abstrakcyjne, myślowe bieguny tego samego procesu dziejowego; ich abstrakcyjna przeciwstawność staje się w historii przeciwstawnością rzeczową, uprzedmiotowioną przez klasowe, społeczno-zawodowe wyodrębnienie polityki i myślenia teoretycznego, działania i poznania; to znów klasowo uprzedmiotowione wyodrębnienie stanowi przesłankę teoriopoznawczą dla filozofii usnutych na pozornej odrębności losów dwu jakby gdyby niezależnych ciągów historycznych: myślenia i działania. Ale każdy realny proces historyczny jest ciągle na nowo powtarzającym się powrotnym zespoleniem teorii i praktyki; im burzliwszy jest ten proces, im większe masy wciąga on w swoją orbitę, im bardziej wzmaga on czynny udział mas w tworzeniu historii,

2 A. Gramsci, Wstęp do dziejów nad filozofia i materializmem historycznym, [w:] Pisma wybrane, t. I, s. $40-41$. 
tym jaskrawiej ukazuje się wzajemne przenikanie się teorii i praktyki, człowieka myślącego i działającego, człowieka i historii. [...] Czymże jest w świetle tych rozważań to, co zwykło się określać jako „wiedzę społeczną”? Jest zarazem intelektualną organizacją praktyki historycznej i zaczynem motywacyjnym tej praktyki; refleksem historii i jej siłą działającą. Wiedza społeczna może być zrozumiana w swej roli społecznej tylko w tym wypadku, jeśli się ją rozpatruje w świetle rzeczywistych procesów, które intelektualnie przetwarza, i praktycznych działań społecznych, które organizuje. Teoria społeczna jest zarówno w genetycznym, jak i funkcjonalnym sensie „przepojona” praktyką i tylko w splocie z praktyką może być analizowana i uprawiana. [...]

Z wszystkich rozważań Gramsciego wyłania się obraz teorii społecznej jako niedającego się odseparować integralnego i zobiektywizowanego elementu procesu historycznego. Historia prowadzi do prób intelektualnego przemyślenia biegu dziejów; w wyniku przemyśleń powstają rozmaite konkurencyjne definicje sytuacji społecznej; te definicje stają się same częścią sytuacji; w ich starciu triumfuje ostatecznie ta, która najpełniej odpowiada interesom i dążeniom jakiejś z masowych sił społecznych; zespala się wtedy z tą siłą, staje się składnikiem jej historycznego działania i w ten sposób współtworzy dzieje. Cechą wyróżniającą marksistowską teorię społeczeństwa, którą Gramsci nazywa „filozofią praktyki”, jest uświadomienie sobie tego właśnie dialektycznego mechanizmu, określającego miejsce i rolę refleksji społecznej, i świadome dążenie do zespolenia się $\mathrm{z}$ działaniem mas.

\section{Filozofia praktyki}

Wizja społecznej historii jako dialektycznego splotu refleksji i działania mas złączonych w procesie praktyki dziejowej - wizja nawiązująca do tych wątków, które łączyły Marksa z klasyczną filozofią niemiecką — stawia Gramsciego w opozycji wobec uproszczonych wydań materialistycznej koncepcji historii, uznanych przez niektóre szkoły za kanon niewzruszony marksizmu. Reprezentowany przez Plechanowa, a potem szeroko podjęty w popularnych wydaniach filozofii marksistowskiej kierunek Gramsci określa jako „materializm wulgarny”3. [...] Gramsci jest zdania, że wulgarno-materialistyczna wersja marksizmu rozpowszechniła się w ruchach masowych wskutek tego właśnie, że intelektualiści tych ruchów pragnęli maksymalnie przybliżyć światopogląd do mas, uczynić go strawnym i zrozumiałym, komunikatywnym i możliwie łatwym do popularyzacji; w rezultacie ,nagięli filozofię do poziomu zdolności percepcyjnych nie rozbudzonych intelektualnie mas". $[\ldots]^{4}$.

\footnotetext{
${ }^{3}$ A. Gramsci, Niektóre zagadnienia zakresu badań nad filozofia praktyki, [w:] ibidem, s. 63.

${ }^{4}$ Ibidem, s. 66.
} 
Wulgarny materializm dzieli z katolicyzmem ludowym przekonanie o istnieniu jakiejś rzeczywistości poza - i przed człowiekiem; rzeczywistości innej niż przedmiot ludzkiej praktyki historycznej, narzucającej ludziom swe prawa, którym muszą się podporządkować, które są dla nich „koniecznością obiektywną”. Dla Gramsciego problem istnienia owej tak czy owak transcendentalnej rzeczywistości jest nie do rozwiązania, a w każdym razie bez znaczenia dla historycznej praktyki. Wiara w owo istnienie jest wytłumaczalna psychologicznie; jest zadośćuczynieniem potrzebie psychicznej ludzi słabych, pozbawionych wiary we własną moc historycznego tworzenia; zarazem krępuje ona swobodę działania mas, zmniejsza zakres wyboru intelektualnego, przyporządkowuje twórczość historyczną wierze w predestynację dziejów, i dlatego winna być zwalczana przez ideologów mas. Ruch masowy, gdy krzepnie, przestaje potrzebować fatalistycznej protezy, bowiem przestaje być ułomny, osiągając przeświadczenie o własnej mocy. Ma wtedy dość sił, by stanąć wobec faktu, że historia jest funkcją jego praktyki. I jest wtedy w stanie przyjąć, że ludziom dany jest w poznaniu ten sam i tylko ten sam świat, który jest im dany w historycznej praktyce; w tym zaś świecie konieczność to tyle właśnie, co uświadomione działanie mas. [...]

Ziarno mistycyzmu tkwi nie tylko w wulgarnych wersjach materializmu. Zawarte jest ono również, zdaniem Gramsciego, w pozytywistycznych koncepcjach wiedzy społecznej, domagających się od socjologii „obiektywnego”, to znaczy niezależnego od praktyki, „czysto-poznawczego” przewidywania zdarzeń historycznych. Tymczasem poznanie społeczne jest integralnym elementem historycznej praktyki i ,przewidywanie” zdarzeń społecznych jest możliwe tylko jako działalność aktywna. „W wyniku dziwacznego odwrócenia perspektywy »uważa się«, że skoro nauki przyrodnicze dają możność przewidywania rozwoju procesów naturalnych, to metodologię historyczną należy uznać za naukową tylko w tej mierze, w jakiej pozwala ona abstrakcyjnie "przewidywać« przyszłość społeczeństwa. [...] W rzeczywistości »przewiduje się« w tym stopniu, w jakim się działa, w jakim czyni się świadome wysiłki, przyczyniając się konkretnie do powstania »przewidywanego« rezultatu. Przewidywanie okazuje się więc nie aktem naukowym, poznawczym, ale abstrakcyjnym wyrazem wysiłku, praktycznym sposobem kształtowania woli zbiorowej”’ O jakichkolwiek innych ,prawach obiektywnych”, niebędących po prostu zbiorowym i świadomym działaniem mas, wykorzystujących szansę historyczną, można mówić tylko o tyle, o ile zakłada się bierność mas, ich stanie na uboczu historycznego procesu. Tylko w okresach bierności mas zachowują swą prawdziwość „prawa statystyczne", będące zwykłym stwierdzeniem powtarzalności pewnej normy postępowania w warunkach względnej stabilności społeczeństwa, w okresach zahamowania twórczości historycznej.

Myliłby się jednak interpretator, który by na podstawie przytoczonych wyżej sądów traktował Gramsciego jako woluntarystę, negującego wagę ograniczeń

\footnotetext{
${ }^{5}$ A. Gramsci, Uwagi krytyczne o „Popularnym zarysie socjologii”, [w:] ibidem, s. 121-122.
} 
praktyki, wyznaczanych przez kontekst historyczny czy powtarzalność zdarzeń dziejowych. Również i Gramsci posługuje się terminem „prawo historyczne”, również i on przypisuje tym prawom znaczną rolę w praktyce mas. Jego pojmowanie praw historycznych jest wszakże niezmiernie odlegle od poglądu określanego jako mistycyzm, a deizującego prawa i konieczność historyczną. W filozofii praktyki, w marksistowskiej teorii społecznej, tak jak ją Gramsci pojmuje, nie może chodzić „o »odkrywanie« metafizycznych praw »determinizmu« ani też o ustalenie »powszechnego« prawa przyczynowości. Chodzi o ukazanie, jak w rozwoju historycznym kształtują się siły względnie trwałe, działające zgodnie z pewną prawidłowością i automatyzmem". Pojęcie prawidłowości i konieczności w rozwoju historycznym, powiada Gramsci, Marks zaczerpnął nie od przyrodników, lecz raczej od ekonomistów. Pojmował on konieczność historyczną jako wypadkową krzyżujących się działań świadomych osobników, jako rezultat względnie trwałej w pewnych okresach historycznych relacji sił społecznych. Źródłem gnozeologicznym pojęcia „prawa historycznego" dla Marksa było ukute w ekonomii politycznej pojęcie „ustalonego rynku”, czyli założenie, że „pewne siły decydujące i stałe są zjawiskiem historycznym, że działanie ich cechuje pewien »automatyzm«, pozwalający w pewnej mierze na przewidywania, na pewien stopień pewności co do przyszłości tych przedsięwzięć indywidualnych, które zgadzają się z owymi siłami, intuicyjnie odgadniętymi i naukowo zbadanymi"6.

W jakim sensie można zatem mówić o „konieczności dziejowej”? Nie ma dla Gramsciego konieczności bez komponenty świadomościowej, bez całościowego procesu praktyki, w którym obok działań masowych występuje nieodłącznie składnik świadomości mas. [...]

W sumie jest wizja socjologii Gramsciego tym, czym jest w istocie marksistowska koncepcja wiedzy społecznej: próbą przezwyciężenia jednostronności zarówno wulgarnego, fatalistycznego materializmu, jak i idealistycznego subiektywizmu; zarówno transcendentalizmu (występującego bądź w materialistycznej, bądź w idealistycznej postaci), jak i woluntaryzmu. Dzieje ludzkie są dla Gramsciego praktycznym działaniem ludzkich mas, w którym świadomość jest równie „obiektywna” jak czyny materialne, czy też czyny materialne — równie „subiektywne" jak świadomość [...].

\section{Społeczna funkcja wiedzy społecznej}

„Wartość historyczną danej filozofii mierzy się jej skutecznością praktyczną"” — i w tym stwierdzeniu zawarty jest układ odniesienia, w jakim analizuje on zadania, które ma do spełnienia „filozofia praktyki” [...]. Szczególne miejsce filozofii

${ }^{6}$ A. Gramsci, Niektóre zagadnienia z zakresu badań nad filozofia praktyki, [w:] ibidem, s. 83, 81.

${ }^{7}$ A. Gramci, Wstęp do studiów nad historia i materializmem historycznym, [w:] ibidem, s. 33. 
praktyki wśród innych filozofii ma zasadzać się na tym, że z owej skuteczności praktycznej, czyli udziału w tworzeniu historii, czyni ona świadomie i celowo swój program. Filozofia praktyki, jak i inne filozofie, rodzi się w kręgach intelektualnych i w nawiązaniu do myśli i pojęć wytworzonych przez filozofów innych szkół i epok; ale nie pozostaje ona „filozofią filozofów”, tzn. refleksją szczupłej garstki specjalistów od socjologicznej refleksji; dąży do opanowania mas, do tego, by stać się światopoglądem większości $\mathrm{i}$ - przetworzona w działanie większości — móc tworzyć historię, ,jedyną prawdziwą", tzn. pełną filozofię. Na tym zasadza się twórczy charakter filozofii praktyki. „Określenie »filozofia twórcza« należy rozumieć w znaczeniu »względnym«, w znaczeniu myśli zmieniającej sposób pojmowania u większości ludzi, a zatem zmieniającej samą rzeczywistość, co jest nie do pomyślenia bez tej większości. Określenie to należy rozumieć również w tym sensie, że filozofia taka uczy, iż nie istnieje jakaś »rzeczywistość sama w sobie«, sama przez się i sama dla siebie, ale jedynie w historycznym związku z ludźmi, którzy ją zmieniają"8. Ale wiemy już z innych rozważań Gramsciego, że światopoglądem większości jest „zdroworozsądkowy” wulgarny materializm. Filozofia praktyki może sama stać się więc światopoglądem większości tylko w jeden sposób: przezwyciężając „rozsądek potoczny", ukazując rzeczywistą strukturę procesu społecznego, doprowadzając do świadomości mas dialektyczny związek między działaniem człowieka a historią jego społecznego świata. Jest to więc filozofia twórcza nie tylko w stosunku do historii, lecz i do wiedzy społecznej ludzi, będących jej przedmiotem i podmiotem zarazem. [...] Refleksja społeczna jest przeto dla Gramsciego posłannictwem, misją społeczną, tworzeniem historii przez thumaczenie masom ich w niej miejsca, przez pobudzanie mas do aktywnego jej tworzenia w imię wyzwolenia fizycznego, ekonomicznego, moralnego i intelektualnego. [...]

Marksowska wizja społecznego świata może zapewnić ludziom tę właśnie rolę świadomych twórców historii - jest bowiem adekwatna do okresu historycznego, jest dzięki temu „historyczna”, predestynowana do stopienia się z działaniem mas w realny „blok historyczny”. Ale jest to tylko jej szansa: dla realizacji szansy wizja ta musi być przyswojona przez masy i spełnienie tego zadania jest właśnie posłannictwem intelektualistów, pragnących wyzwolenia człowieka $\mathrm{z}$ więzów rzeczywistych i urojonych. [...]

\section{Gramsciego koncepcja socjologii: próba interpretacji}

Spuścizna teoretyczna Gramsciego obejmuje wyłącznie niemal luźne uwagi, formułowane zwykle na marginesie problemów praktycznych, najczęściej w kon-

\footnotetext{
${ }^{8}$ Ibidem, s. 32.
} 
tekście krytycznego rozbioru systemów teoretycznych innych filozofów i socjologów. Nie zawiera ona żadnego opracowania systematycznego, lecz raczej zbiór konspektów do przyszłych studiów, w których realizacji przeszkodziła Gramsciemu przedwczesna śmierć w faszystowskich kazamatach. Przedstawiony wyżej szkic jest więc próbą rekonstrukcji systemu, którego Gramsci nigdy nie przedstawił w zwartej postaci, jest próbą egzegezy tekstów wielkiego myśliciela dla odtworzenia sensu podstawowych dlań pojęć i kształtu podstawowych dyrektyw jego koncepcji wiedzy społecznej.

Dokonując tej próby, posługiwałem się nierzadko terminem „socjologia” dla określenia wiedzy, której model Gramsci mozolnie i w niezwykle oryginalny sposób budował. Gwoli prawdy stwierdzić jednak wypada, że słowa „socjologia" Gramsci nie lubił podobnie jak Marks; dla Marksa termin ten kojarzył się z historiozofią Comte'a, dla Gramsciego zaś - z pozytywistyczną odmianą refleksji społecznej, w istocie likwidatorską wobec socjologii XIX-wiecznej. Dlatego Gramsci niejednokrotnie krytykował zjadliwie i z sarkazmem nie te lub inne twierdzenia socjologów zawodowych, lecz „socjologię" w ogóle; używał uparcie dla oznaczenia własnego modelu wiedzy społecznej terminu ,filozofia praktyki”, by przeciwstawić ów model również i w nazwie nie tej lub innej szkole socjologicznej, lecz „socjologii” w ogóle. Pobieżna nawet analiza znaczeniowa wskaże wszelako, że zawsze w takich wypadkach obiektem jego krytyki była jedna tylko maniera uprawiania socjologii, czy też jedna tylko szkoła socjologiczna — ta mianowicie, która postulowała model wiedzy społecznej skrojony na wzór modelu przyrodoznawstwa i która za główny swój cel uznała poszukiwanie pozahistorycznych praw statystycznych pozwalających w sposób właściwy fizyce „przewidywać” zachowania jednostek ludzkich; innymi słowy — pozytywizująca szkoła w socjologii, którą dziś zakwalifikowalibyśmy do któregoś z bardziej radykalnych czy bardziej łagodnych odgałęzień pluralistycznego behavioryzmu. $Z$ drugiej strony, Gramsci sam uprawiał, i to w sposób znakomity, socjologię; potrzebna byłaby bardzo nieliberalna, sekciarska $\mathrm{w}$ istocie definicja socjologii, aby poza delimitowaną przez nią klasą studiów socjologicznych pozostały np. prace Gramsciego o tworzeniu się inteligencji czy o organizacji szkolnictwa i kultury, czy wreszcie niezwykle głęboki teoretycznie, choć zarysowany w tezowej niemal formie Nowoczesny książę. Obie te okoliczności upoważniają do posługiwania się terminem „socjologia” dla oznaczenia postulowanej przez Gramsciego koncepcji wiedzy społecznej; rezygnacja $z$ owego terminu byłaby pośrednio uznaniem prawomocności monopolistycznych roszczeń jednej ze współczesnych szkół socjologicznych do tej nazwy.

Inna sprawa budzi wszakże trudności poważniejsze. Rozważania Gramsciego obfitują w terminy, a co ważniejsze, w problemy niezwyczajne współczesnej socjologii akademickiej, zaniedbane lub porzucone przez większość szkół niemarksistowskiej socjologii. Ktoś akceptujący ukute w tych szkołach, a aspirujące 
do monopolizmu na nowoczesność i naukowość, wyobrażenia o przedmiocie socjologii i o granicach sfery, którą wolno się zajmować badaczowi aspirującemu do uprawiania nauki, może podać w wątpliwość przynależność wielu rozmyślań Gramsciego do socjologii. Jest to wszakże kwestia gustu, choć gusty modne i w jakiejś grupie rozpowszechnione są produktem bynajmniej nie indywidualnej inwencji. Można przez „socjologię” rozumieć (i rozumie się w istocie) zainteresowania bardzo rozmaitymi sprawami, oglądanymi z bardzo rozmaitych perspektyw. W szczególności wszakże wyróżnić można dwa podstawowe typy pojmowania socjologii, do których różne jej koncepcje mniej lub bardziej się zbliżają. Charakterystyki zasadnicze tych typów wyznacza z kolei pojmowanie zastosowań socjologii. W jednym wypadku rozpatruje się socjologię pod kątem jej zastosowań ideologicznych, tzn. jako wizję organizującą doświadczenia zbiorowe grup ludzkich i motywacje ich działań kolektywnych, i w ten sposób integrującą grupę w sferze świadomości i zachowań praktycznych. W drugim wypadku rozpatruje się socjologię z punktu widzenia jej zastosowań technicznych, tzn. jako wiedzę o prawdopodobieństwie wystąpienia określonych związków między zjawiskiem A a zjawiskiem B, umożliwiającą osiąganie pożądanych zjawisk i unikanie zjawisk niepożądanych; w wypadku wiedzy społecznej idzie, rzecz jasna, o możność manipulowania zachowaniami innych ludzi. Socjologia Gramsciego należy do pierwszej kategorii, gdy szkoły najmożniejsze socjologii współczesnej poza marksizmem zaliczają się z grubsza do kategorii drugiej. W tej właśnie okoliczności tkwi przesłanka wszystkiego, co różni socjologię Gramsciego od tego, co uważa się za socjologię w większości zachodnich ośrodków akademickich i badawczych. W świecie dzisiejszym za wspólną nazwą „socjologia” kryją się w istocie dwie całkiem różne motywacje intelektualne i kierunki poszukiwań badawczych. Dla Gramsciego, jak i dla marksizmu w ogóle, funkcja poznawcza socjologii jest nieodłączna od jej funkcji ideologicznej, integrującej historycznie twórczy ruch społeczny; dla innych szkół, szczególnie dla pozytywistycznego nurtu w socjologii, racją bytu wiedzy społecznej jest jej funkcja techniczna (co nie znaczy, by socjologie tego typu wolne byty od funkcji ideologicznej).

Ta właśnie cecha propagowanego przez Gramsciego modelu socjologii zasługuje na baczną uwagę. Rzecz w tym, że często - wbrew prawdzie - upatruje się swoistość socjologii marksistowskiej w pewnych twierdzeniach orzekających o rzeczywistości społecznej, przyjętych na gruncie marksizmu, a uznanych za fałszywe przez przedstawicieli innych szkół. W najlepszym wypadku upatruje się oryginalność socjologii Marksa i jego uczniów w swoistych dyrektywach metodologicznych, przez nią lansowanych i częściowo zasymilowanych, a częściowo potępianych przez inne szkoły. Obydwa poglądy nie wydają mi się ścisłe. Trudno byłoby związać z socjologią marksistowską jakiś stały, niepodlegający modyfikacjom zbiór zdań orzekających o społeczeństwie, jako że wszelkie zdania 
tego typu podlegają weryfikacji empirycznej, czy — poprawniej — „weryfikacji przez historię" i w świetle nowych zdarzeń czy nowych faktów muszą być modyfikowane. Co się tyczy szczególnych dyrektyw metodologicznych, to swoistość dyrektyw, kojarzonych zwykle z nazwiskiem Marksa, wynika ze swoistości socjologii, jaką Marks uprawiał, i wynikającej stąd z kolei swoistości problemów, które rozwiązywał; owe dyrektywy są jak najściślej związane z typem zadań poznawczych, a zatem są funkcją pojmowania modelu i zadań społecznych wiedzy o społeczeństwie. Nie w twierdzeniach i nie w metodologii, a w każdym razie nie tylko w nich tkwi swoistość marksistowskiej koncepcji socjologii.

Tym, co szczególnie ostro różni model socjologii marksistowskiej od modeli konstruowanych przez szkoły występujące dziś pod mianem nowoczesnych i naukowych (jeśli nie ,jedynie naukowych"), jest, jak to dobitnie widać u Gramsciego, przyjęcie procesu historycznego jako układu odniesienia dla oceny ważności problemów poznawczych i wartości rozwiązań, w ich sprawie zgłaszanych. Wiedza społeczna jest tu pojmowana jako integralny element „bloku historycznego, dynamicznej rzeczywistości społecznej, ruchu mas, twórczości historycznej”. Stąd wyczulenie ogromne na ideologiczny aspekt każdej wizji społeczeństwa, skłonność do rozpatrywania wszelkiego, w tym i własnego, systemu twierdzeń o społeczeństwie pod kątem głównie jego ideologicznie integrujących bądź dezintegrujących funkcji. Ten kąt patrzenia na socjologię nie jest u marksistów „skrzywieniem doktrynalnym"; dogmatycznie błędne mogą być poznawcze produkty takiego spojrzenia, ale nie perspektywa, z której się patrzy; dla marksistów wiedza społeczna „urzeczywistnia się” społecznie właśnie w swej funkcji ideologicznej, $\mathrm{w}$ tej bowiem funkcji staje się ona czynnym składnikiem historii.

$\mathrm{Z}$ tych samych przyczyn wypływa też preferowanie przez marksistów pytania: „Komu to służy, jakie skutki dla kogo w życiu społecznym pociąga?” — przy analizie jakiejkolwiek teorii społecznej, skłonność do rozpatrywania każdej doktryny socjologicznej w układzie odniesienia klasowych interesów i dążeń. Łączy się z tym tak ostro sformułowany przez Gramsciego postulat wyboru konsekwencji historycznych dla oceny walorów doktryny socjologicznej; zauważmy, że Gramsci zamiast parą pojęć „,prawda-fałsz”, obarczonych tradycyjnymi przyrodoznawczymi użytkami, woli posługiwać się w ocenie teorii społecznych parami terminów „historyczna-niehistoryczna”, ,adekwatna-nieadekwatna”. Gdy się pojmuje socjologię jako tylko zbiór twierdzeń orzekających o rzeczywistości, można formułować postulaty weryfikowalności empirycznej w sensie laboratoryjnego doświadczenia indywidualnego badacza; można sądzić, że się obraca w sferze, w której wypracowane w przyrodoznawstwie operacyjne sensy pojęć „prawda" i „fałsz” znajdują pełne zastosowanie. Gdy się jednak pojmuje socjologię szerzej, jako twórczy czynnik integracji działań masowych, wtedy tradycyjne instrumenty laboratoryjnej weryfikacji twierdzeń przestają być wystarczającym sprawdzianem walorów doktryny, jeśli w ogóle dają się do tego celu zastosować. Socjolo- 
gia w swej funkcji ideologicznej jest również „weryfikowalna empirycznie”, ale sprawdzianem staje się w tym wypadku proces historyczny; jeśli doktryna znalazła drogę do ruchów masowych, pobudziła je do czynu i doprowadziła w związku z tym do realizacji zawartej w niej wizji świata społecznego, tym samym zdała egzamin ze swej „historyczności”; [...] W tym sensie sprawdzianem poprawności („historyczności” w języku Gramsciego) teorii rewolucji jest rewolucja sama, mimo, a w istocie właśnie dzięki temu, że sformułowanie teorii rewolucji, zespalając się z ruchem masowym, samo stało się ważkim czynnikiem sprawczym samej rewolucji $[\ldots]$.

Mowa była poprzednio o koncepcji socjologii C. Wright Millsa, najbardziej bodaj ze wszystkich szkół współczesnych zbliżonej do modelu marksistowskiego. Mills postulował „socjologię zaangażowaną” w tym sensie, że rozpowszechniającą wśród ludzi „wyobraźnię socjologiczną”, umiejętność oglądania własnej biografii na tle historii i w związku z nią. Partnerem socjologa w tej koncepcji jest jednostka, osaczona przez potężne, a obce jej i niezrozumiałe dla niej instytucje, które pozostawiają jej nikłe granice swobody wyboru. Wyobraźnia socjologiczna ma służyć rozszerzeniu tej sfery wyboru, ma umożliwić zaangażowanie jednostki w wysiłku przekształcenia instytucji, przystosowania ich do ludzkich potrzeb. Jest w tej koncepcji wiele podobieństwa do postulatów wysuwanych w imieniu marksizmu przez Gramsciego. Partnerem intelektualisty-myśliciela jest dla Gramsciego nie człowiek indywidualny, stający sam na sam wobec trudnego zadania wyboru, lecz masa, ruch masowy, który intelektualista rozbudza i którego wysiłek integruje z pomocą formułowanej przez siebie definicji sytuacji i jej perspektyw. Millsowi brakowało właśnie owego wyczulenia na potencje twórcze ruchu masowego; koncepcja socjologii Millsa miała wiele znamion prometejskiego mesjanizmu, gdy w koncepcji Gramsciego intelektualista pełni raczej rolę zaczynu, wstępnego bodźca w stosunku do głównego aktora historii, jakim jest ruch masowy. Zarówno Mills, jak i Gramsci traktują wszakże socjologię w pierwszym rzędzie jako dostarczyciela orientacji historycznej, czyli w jej funkcji ideologicznej - i ten fakt zbliża ich nawzajem do siebie. O krok dalej znajdujemy wszelako znowu różnicę: dla Millsa „dać orientację" to tyle, co umożliwić działanie skuteczne przez dostarczenie wiedzy o historii; dla Gramsciego - to w pierwszym rzędzie pobudzenie do tworzenia historii przez intelektualną organizację działań. Być może, w tej rozbieżności znajdziemy motywacyjne wyjaśnienie faktu, że Mills u schyłku życia, rozczarowany do wszelkich ruchów masowych, pokładał nadzieję w samotnej walce intelektualistów, gdy Gramsci apelował zawsze do mas, do klasy robotniczej, do partii masowej.

Wydaje się, że w sposobie pojmowania wiedzy społecznej przez Gramsciego tkwi niejedna zasadnicza wskazówka dla wyboru układu odniesienia, najbardziej adekwatnego do analizy teorii społecznych. Podkreślam: teorii społecznych, bowiem podejście Gramsciego obliczone jest na wielkie wizje ludzkiego świata, 
systemy światopoglądowe o wyraźnie zarysowanych funkcjach ideologicznych; funkcje takie, ze względu na konfliktową naturę zjawisk społecznych, będących przedmiotem socjologii, występują w jakimś stopniu we wszystkich systematycznych dociekaniach socjologicznych; ale, jak się zdaje, dla wielu kierunków współczesnych badań charakterystyczne jest „wchodzenie w blok historyczny” przez furtkę techniki, a nie ideologii; badania nad kondycjonowaniem zachowań jednostkowych oddziałują na proces historyczny przez to, że umożliwiają posiadaczom odpowiednich środków manipulacji kształtowanie zachowań ludzi zgodnie z własnym pragnieniem. Idea takiej wiedzy społecznej jest Gramsciemu obca; myśl o masach jako twórcy historii jest u Gramsciego zarówno zdaniem teoretycznym, jak i postulatem moralnym, prawa statystyczne zakładające stałość i stabilność zachowań masowych i oferujące środki dla manipulacji tymi zachowaniami są więc dlań zarazem teoretycznie wadliwe i moralnie potępienia godne. Gramsci zarówno nie wierzy w możliwość takiej socjologii, jak i odrzuca jej program ze względów etycznych. Jedyne, co ostaje się z funkcji wiedzy społecznej jako trwały składnik dynamicznego procesu historycznego, co jest trwalsze niż przejściowe okresy ujarzmienia i pasywizacji mas — to właśnie rola socjologii jako wizji organizującej doświadczenie, motywacje i działania mas. [...]

[C]zytelnik znajdzie u Gramsciego wizję ludzkiego świata najbardziej optymistyczną ze współcześnie lansowanych, przepojoną wiarą w siły twórcze człowieka i skonstruowaną w tym jedynie celu, by owe siły rozwijać i pobudzać do czynu. 